University of Nebraska - Lincoln

DigitalCommons@University of Nebraska - Lincoln

Publications from USDA-ARS / UNL Faculty

U.S. Department of Agriculture: Agricultural

Research Service, Lincoln, Nebraska

$1-18-2008$

\title{
Opportunities and roadblocks in utilizing forages and small grains for liquid fuels
}

\author{
Gautam Sarath \\ University of Nebraska-Lincoln, Gautam.sarath@ars.usda.gov \\ Robert B. Mitchell \\ University of Nebraska-Lincoln, rob.mitchell@ars.usda.gov \\ S. E. Sattler \\ USDA-ARS, Scott.Sattler@ars.usda.gov \\ Deanna L. Funnell \\ University of Nebraska-Lincoln, dfunnell2@unl.edu \\ Jeffrey F. Pedersen \\ University of Nebraska-Lincoln, jpedersen1@unl.edu \\ See next page for additional authors
}

Follow this and additional works at: https://digitalcommons.unl.edu/usdaarsfacpub

Part of the Agricultural Science Commons

Sarath, Gautam; Mitchell, Robert B.; Sattler, S. E.; Funnell, Deanna L.; Pedersen, Jeffrey F.; Graybosch, Robert A.; and Vogel, Kenneth P., "Opportunities and roadblocks in utilizing forages and small grains for liquid fuels" (2008). Publications from USDA-ARS / UNL Faculty. 218.

https://digitalcommons.unl.edu/usdaarsfacpub/218

This Article is brought to you for free and open access by the U.S. Department of Agriculture: Agricultural Research Service, Lincoln, Nebraska at DigitalCommons@University of Nebraska - Lincoln. It has been accepted for inclusion in Publications from USDA-ARS / UNL Faculty by an authorized administrator of DigitalCommons@University of Nebraska - Lincoln. 


\section{Authors}

Gautam Sarath, Robert B. Mitchell, S. E. Sattler, Deanna L. Funnell, Jeffrey F. Pedersen, Robert A. Graybosch, and Kenneth P. Vogel 


\title{
Opportunities and roadblocks in utilizing forages and small grains for liquid fuels
}

\author{
Gautam Sarath · Robert B. Mitchell • Scott E. Sattler • \\ Deanna Funnell $\cdot$ Jeffery F. Pedersen $\cdot$ \\ Robert A. Graybosch · Kenneth P. Vogel
}

Received: 3 October 2007 / Accepted: 3 December 2007 / Published online: 18 January 2008

(C) USDA-Agricultural Research Service, US Government Agency 2008

\begin{abstract}
This review focuses on the potential advantages and disadvantages of forages such as switchgrass (Panicum virgatum), and two small grains: sorghum (Sorghum bicolor), and wheat (Triticum aesitvum), as feedstocks for biofuels. It highlights the synergy provided by applying what is known from forage digestibility and wheat and sorghum starch properties studies to the biofuels sector. Opportunities therefore, exist to improve biofuel qualities in these crops via genetics and agronomics. In contrast to cereal crops, switchgrass still retains tremendous exploitable genetic diversity, and can be specifically improved to fit a particular agronomic, management, and conversion platform. Combined with emerging studies on switchgrass genomics, conversion properties and management, the future for genetic modification of this species through conventional and molecular breeding strategies appear to be bright. The presence of brown-midrib mutations in sorghum that alter cell wall composition by reducing lignin and other attributes indicate that sorghum could serve as an important model species for $\mathrm{C}_{4^{-}}$ grasses. Utilization of the brown-midrib traits could lead to the development of forage and sweet sorghums as novel biomass crops. Additionally, wheat crop residue, and wheat and sorghum with improved starch content and composition represent alternate biofuel sources. However, the use of wheat starch as a biofuel is unlikely but its value as a model to study starch properties on biofuel yields holds significant promise.
\end{abstract}

JIMB-2008: BioEnergy-Special issue.

G. Sarath $(\bowtie) \cdot$ R. B. Mitchell · S. E. Sattler · D. Funnell

J. F. Pedersen · R. A. Graybosch · K. P. Vogel

Grain, Forage and Bioenergy Research Unit,

USDA-ARS, 314 Biochemistry Hall,

University of Nebraska, East Campus,

Lincoln, NE 68583-0737, USA

e-mail: Gautam.Sarath@ARS.USDA.GOV
Keywords Biofuels $\cdot$ Forage digestibility $\cdot$ Sorghum · Switchgrass $\cdot$ Wheat

\section{Introduction}

Humans have been utilizing solar energy captured by plants for millennia, principally for food, fiber and fuel. The use of coal and oil (also predominantly formed from photosynthetic organisms), greatly reduced the need for wood as fuel, but enhanced its use in construction and paper. Similarly, agricultural mechanization led to a major release of land maintained in pastures and haylands for feeding horses and for other uses, mainly grain and oilseed crop production [100]. All of these changes have done much to alter the land and energy use over the course of the last century. However, within a fairly short time interval, energy demands have greatly escalated, once again requiring the need to directly exploit plants as fuel and feedstock alternatives $[39,55,60,76,96]$. Because of urbanization, a reduced agricultural land base is now being expected to provide food, fiber, and energy for an expanding population.

In the USA, a national goal of replacing $30 \%$ of petroleum gasoline with liquid fuels derived from lignocellulosic materials by the year 2030 has been established: http:// www1.eere.energy.gov/biomass/pdfs/final_billionton_vision_ report2.pdf (page 18). Achieving this goal depends on two major components (1) developing plants and production systems to generate this dry tonnage and (2) developing the requisite biorefining capabilities, making conversion of biomass efficient and economically viable. Considerable resources have been allocated by governmental and nongovernmental agencies to transform lignocellulosic-based biofuels into a commercially successful venture. Attaining 
a good mix of traditional and alternative fuels could have a lasting impact on US agriculture well into the twenty-first century. When combined with sustainable practices, and low-input cultivation, commercially successful plant-based biofuel feedstocks also have the promise to revitalize rural America.

Pressure that might be applied on arable land for raising biofuel crops versus food crops potentially represents a major hurdle, especially if this pressure will lead to increased food prices [16]. The use of native perennial plants, forage sorghums and small grains could mitigate some of the competition between biofuel and food crops. Opportunities also exist to sustainably utilize agricultural residues, such as corn stover or wheat straw in select locations of the US. A serious constraint will be to ensure that residue removal does not impact soil health and/or negatively influence future crop yields [42, 45].

In this review, we highlight three herbaceous species, namely, switchgrass (Panicum virgatum L.), sorghum [Sorghum bicolor (L.) Moench.] and wheat (Triticum aestivum L.) that have been suggested as biofuel feedstocks. Each species can fill a unique niche as a feedstock in the USA, and could serve as alternate feedstocks for a biorefinery (Fig. 1). Both sorghum and switchgrass are relatively drought tolerant warm-season crops that are harvested in late summer or early fall. Wheat and other small grains are generally harvested in late spring or early summer but are harvested later in the summer in northern latitudes.
Successful utilization of feedstocks for fuels rests on documenting the environmental sustainability of production systems and allying fears over competition with food crops. Although some of these long-term concerns are difficult to evaluate, there is extensive research experience with pastures, soil erosion, soil-amelioration, plant breeding and production systems, that can be successfully employed to generate new (e.g. switchgrass, other forage grasses) and existing crops (e.g., sorghum, sugarcane) for the biofuels sector in a sustainable manner. A critical factor that will drive the economic viability of the bioenergy sector will be sustained increases in plant biomass yield to ensure feedstock supplies for energy without adversely affecting food supplies.

The principal components of plant biomass include stems, leaves and reproductive structures. The ratios of these plant organs in biomass will depend on the plant species, plant genotype and time of harvest. For example, switchgrass biomass will be primarily composed of stems and leaves, whereas sorghum biomass could have stems, leaves and seeds. Differences in components and therefore in composition present challenges in terms of pretreatment protocols and mixtures of hydrolytic enzymes that will be required for converting biomass to sugars, and ultimately into fuel [25].

Herbaceous plant dry matter consists of cell walls and cell contents present at the time of harvest. Grass stems will contain significantly more cell wall material as compared to
Fig. 1 Historical range of switchgrass in North America, and acres planted to sorghum and wheat in 2006 in USA (From NASS)

\section{Historical range of switchgrass plants}

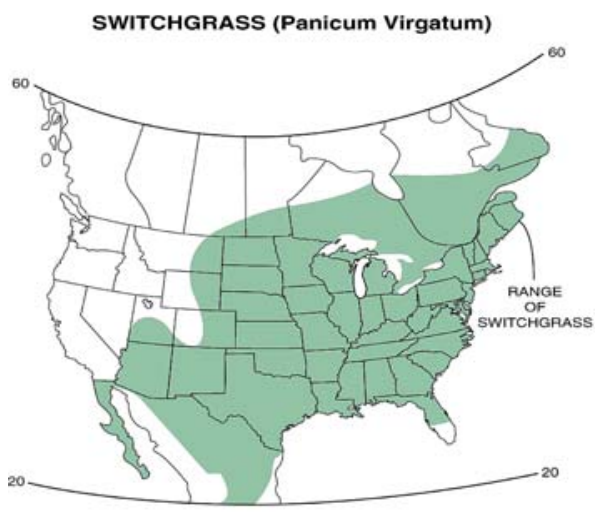

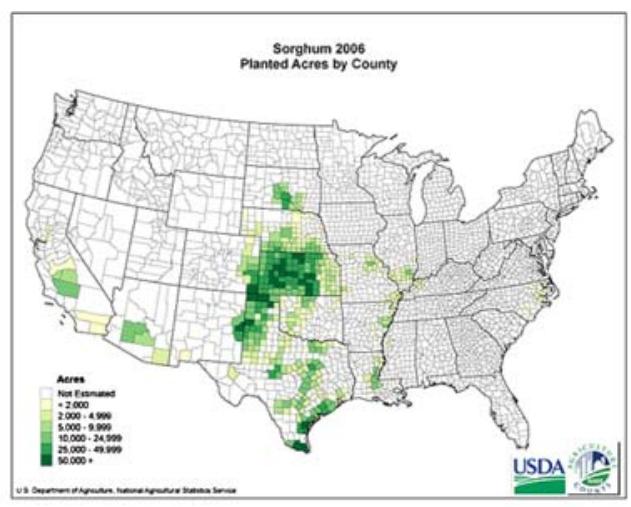

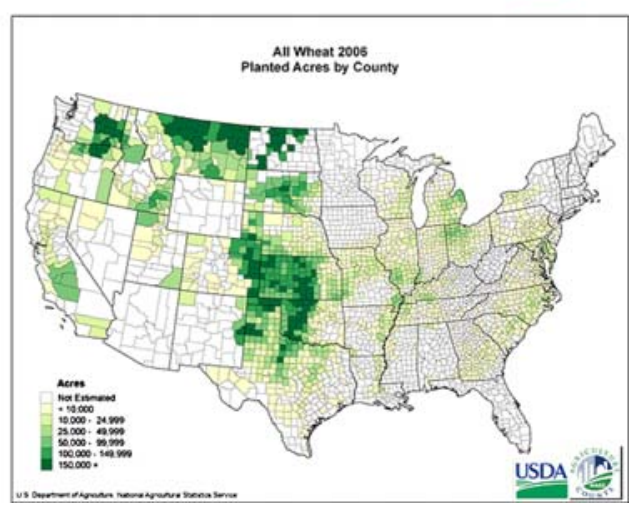


leaves, whereas seeds will be predominately made up of starch. Grass cell walls contain three major polymers, namely, cellulose, hemicellulose and lignin. The primary plant cell wall is composed mostly of cellulose when first formed [21]. This primary cell wall is subsequently modified and transformed into a secondary cell wall with greater accretions of cellulose, hemicellulose and lignin. The relative amounts of cell wall polymers will depend on the ultimate developmental fate of a given cell, for example, xylem cells will have extensively lignified walls at maturity, whereas pith parenchyma will be less lignified [21, 44, 50]. Both hemicellulose and lignin are complex polymers [7]. Higher plants contain guaiacyl (G) and sinapyl (S) lignin derived from ferulic and sinapic acids, respectively. Grass cell walls also contain $p$-hydroxyphenyl $(\mathrm{H})$ lignin, derived principally from 4-coumaric acid [7, 27, 36].

Of the two sugar-derived cell wall polymers, cellulose will yield glucose, and hemicellulose will yield mostly pentoses (xylose) and some hexoses. The ratio of glucose to xylose will depend on the relative amounts of cellulose to hemicellulose, and on the sugar composition of the hemicellulose. These amounts are likely to vary with each feedstock [25, 26]. Lignin can render feedstock recalcitrant towards glucanse degradation [17, 104], and its breakdown during biomass pretreatment can yield phenolic fermentation inhibitors as well [52]. Increasing cell wall carbohydrate (principally as cellulose) content in biomass can be expected to increase liquid fuel yield. Decreasing lignin content is also expected to enhance cellulose breakdown, and has been a major target for conventional and molecular breeding [17, 18, 87-89, 104]. However, lowering lignin content could have a negative impact on plant fitness and survivability of perennial species under field conditions $[12,70]$.

Lignin negatively affects digestibility in herbivores and improvements in forage digestibility can be accomplished by genetically reducing lignin content of the plants. For example, the commonly utilized brown midrib mutants (bmr) in forage maize and sorghum are mutations in genes for enzymes of the lignin biosynthesis pathway resulting in plants with reduced lignin and greater digestibility $[1,2,6$, $8,13,14,19,20,33,36,38,47,75,105]$. This suggests that accessibility of cellulose and hemicellulose by rumen microorganisms has been improved by lowering or changing the types and amounts of lignin present in cell walls. Biorefineries present a comparable system where improved cellulose breakdown with enzyme mixtures rather than rumen bacteria will be utilized to deconstruct cell walls to sugars. Thus at first pass, the long-term experience in forage breeding and genetics can be readily applied to generate herbaceous feedstocks with greater conversion potential by applying assays that approximate animal digestibility as a screen. Such broad selection is likely to result in plants with a divergent array of cell wall characteristics that favor conversion to liquid fuels for individual feedstocks.

Breeding herbaceous feedstocks will need efficient and effective tools to guide selection of plants with desired traits. These include in-vitro dry matter digestibility (IVDMD) and the related fiber detergent digestion protocol, which have been a mainstay in forage breeding programs [14, 24, 41, 46, 58, 104, 105]. IVDMD has been used to evaluate plant germplasm for biomass use [91]. Near-infrared reflectance spectroscopy (NIRS) [4] is another reliable method for screening large plant populations within a breeding program, but NIRS derived equations have to be based on wet-lab data. For bioenergy crops, appropriate assays are likely to include a combination of high-throughput assays (for example NIRS), mid-throughput assays (for example gas generation; [107, 108], and lower throughput assays (for example direct biomass conversion to ethanol; [26]). All of these assays are currently in use and is likely that other methods, such as simultaneous saccharification and catabolism (SSC) which measures bacterial growth as a function of released sugars (M. P. Scott, USDA-ARS, personal communication), DNA and protein microarrays to evaluate biomass and directly select for specific genes or alleles will be developed. Utilization of genomic and EST sequences from switchgrass should accelerate markerassisted selection in the near term [57, 97, 98]. A combination of techniques will need to be used to analyze and develop new bioenergy genotypes for enhanced yield and quality. However, growing dedicated bioenergy crops with or without removal of agricultural residues is going to require new agronomic and harvest management strategies to maintain long-term economic and environmental sustainability.

\section{Switchgrass}

Switchgrass (Panicum virgatum L.) is a native, warm-season $\mathrm{C}_{4}$-species of the tall grass prairies of the US [101]. Its historic range extended from Mexico to Canada (Fig. 1). Currently switchgrass is grown as a hay and conservation crop, predominantly on marginal land. An assessment of herbaceous feedstocks by the US Department of Energy (DOE) initiated in the late 1980s led to the selection of switchgrass as a primary biofuel feedstock and much of this work has been reviewed [54]. Since that time, work at several governmental agencies (for example: [15, 30, 104, 105] and other institutions [9, 22, 49, 56, 61, 66]), have contributed to the development of switchgrass as a viable biomass feedstock. Much of the breeding and agronomic research on switchgrass has been reviewed recently [69, 81, 101].

A unit of switchgrass biomass is a tiller (stem) with attached leaves and inflorescences, principally the above 
ground parts of the plant. The proportion of leaves to stems is an important determinant in biomass yields and potentially for conversion. On a component basis, leaves are generally lower in lignin, higher in solubles, cellulose and hemicellulose, whereas switchgrass stems will contain greater proportions of lignin and cellulose. Although stems have higher lignin content as compared to leaves, stem tissues are denser, and possess greater amounts of cell wall materials on a mass basis.

For an individual tiller, internodes near the top of the plant will be less lignified as compared to internodes closest to the base of the plants. For switchgrass cultivar Kanlow, the basal internodes contained almost twice the amount of lignin compared to the most apical internode [83]. In switchgrass tillers, the xylem, a band of cortical sclerenchymatous fibers just beneath the epidermis, and the fiber sheath surrounding the vascular bundles are most highly lignified tissues [83] (Fig. 2). The ground parenchyma display varying levels of secondary wall formation and its subsequent lignification's appears to be genotype, environment, and maturity dependent $[34,83]$. These data indicate that harvesting heights and time of harvest will impact biomass quality and its eventual conversion to ethanol or bioenergy $[3,26,83]$. Variations in biomass quality and convertibility arise from the ratio of leaves to stems, and the amount of starch and simple sugars relative to cell wall accreted polymers. Younger plant tissues will have less biomass and contain more soluble sugars and starch and less lignocellulose; their conversion efficiencies to ethanol are likely to be greater. In contrast, older tissues will have greater total biomass and lignocellulose, but are likely to exhibit lower conversion to ethanol. For example, Dien et al. [26] found that switchgrass harvested at boot-stage (inflorescence emergence) was converted to ethanol with greatest efficiency and plants harvested at a later date exhibited less ethanol potential. In another study, switchgrass plants harvested in the fall or the following spring displayed significant differences in biomass quality, indicating that quality slowly deteriorates over time if left in the field [3]. These key studies provide starting points to evaluate switchgrass quality parameters affected by agronomics and management and provide impetus to investigate effects of post-harvest storage and handling of biomass.

As mentioned earlier, biomass digestibility in animals is negatively correlated with high lignin $[12,13,20,58]$ and potentially with lowered conversion to ethanol [26]. Previous studies indicate that all three cell wall polymers can be changed through selective breeding for digestibility in

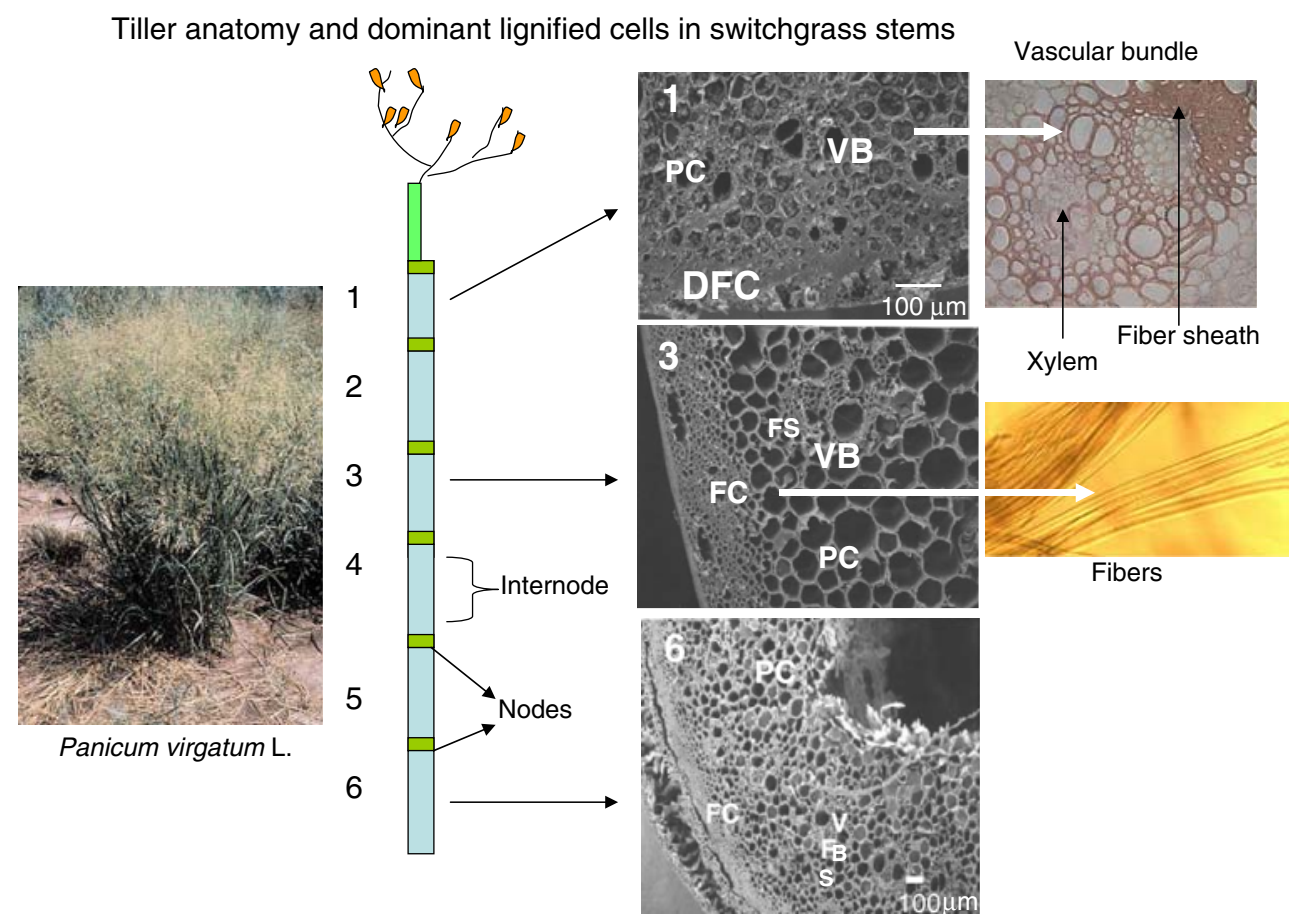

Fig. 2 A switchgrass plant, and anatomy of a switchgrass tiller. Scanning electron micrographs indicate changes in anatomy between the apical (1), mid (3) and bottom (6) internodes along a tiller. In the most apical internode (1), the cortical fiber cells are present but still developing $(D F C)$. Vascular bundles $(V B)$ and parenchyma cell $(P C)$ are also labeled. In the middle internode $(3)$, the cortical fibers are well developed $(F C)$ and the vascular bundles $(V B)$ are enclosed by a fiber

sheath $(F S)$. The parenchyma cells $(P C)$ are larger than in the top internodes and display more thickened cell walls. The bottom internode (6) contains well-developed cortical fibers $(F C)$, which have become lignified and thick-walled. Considerable thickening of the parenchyma $(P C)$ cell walls are also observed. Light micrographs of the xylem and fiber sheath surrounding a vascular bundle and cortical fibers are shown. These two tissues contain significant amounts of lignocellulose 
switchgrass $[75,103,106]$. Analyses of these plants at the anatomical and biochemical levels ([84]; Sarath, Akin, Vogel Mitchell and Dien, unpublished) indicate that specific cell types, cell wall content, biomass accessibility to cellulases and esterases, and ethanol content have been altered. Thus structural (plant anatomy) and compositional changes (cell walls) modified as a result of divergent selection for dry matter digestibility have yielded switchgrass germplasm with improved conversion to ethanol. Taken together, published and unpublished information show that switchgrass plants with better quality parameters can be developed through conventional breeding for higher IVDMD. These plants can then be selectively improved for stand establishment, yield and conversion properties through combination of breeding strategies, employing a range of analytical platforms.

Switchgrass is established through direct seeding. Outside abiotic factors, the two major problems affecting establishment are weed competition and seed quality [85, 101]. With appropriate agronomics and normal climatic conditions switchgrass fields can achieve 50\% of full yield potential after the first year [85]. A similar situation exists for other perennial forage grasses [59]. Establishing an acceptable stand in the seeding year and obtaining harvestable biomass, the establishment year has very significant economic effects on the production of switchgrass for bioenergy. Switchgrass fields with a stand frequency of 40 $50 \%$ or greater indicate a successful stand, whereas stand frequency from $25-50 \%$ were marginal to adequate, and stands with less than $25 \%$ frequency may require overseeding or re-establishement $[85,101]$. Successful, first year harvestable stands require the use of high quality seed and herbicides for weed control. A basic set of herbicides for weed control in switchgrass is now available for use in most regions of the USA [101]. Once established, switchgrass stands require only limited, periodic herbicide applications.

Switchgrass production is optimized and quality stands are maintained by good fertility management. Switchgrass can tolerate low fertility conditions, but applied $\mathrm{N}$ increases dry matter production. However, an important concern is the fate of the soil-applied $\mathrm{N}$ and its potential to leach out of the root zone and become a potential groundwater contaminant. The amount of applied $\mathrm{N}$ required by switchgrass depends on the yield potential of the site, productivity of the cultivar, and other management practices being used [102]. In South Dakota Conservation Reserve Program (CRP), lands dominated by switchgrass, Mulkey et al. [61] reported that application of $56 \mathrm{~kg} \mathrm{~N} \mathrm{ha}^{-1}$ increased total biomass, and there was no benefit to applying more N. In Nebraska and Iowa, switchgrass cv "Cave-in-Rock" yield increased as $\mathrm{N}$ rate increased from 0 to $300 \mathrm{~kg} \mathrm{~N}^{-1}$, but residual soil $\mathrm{N}$ increased when more than $120 \mathrm{~kg} \mathrm{~N} \mathrm{ha}^{-1}$ was applied [102]. These authors concluded that approximately $10-12 \mathrm{~kg} \mathrm{ha}^{-1}$ year $^{-1}$ of applied $\mathrm{N}$ is needed for each $1 \mathrm{Mg} \mathrm{ha}^{-1}$ of biomass yield [102].

The current focus on harvesting biomass feedstocks is to maximize dry matter production. Research to date indicates single harvest systems maximize economic switchgrass biomass yields and have maximized switchgrass biomass recovery. For example, Sanderson et al. [82] harvested "Alamo" switchgrass one to four times per year for 4-years in Texas. They concluded that a single harvest in mid-September maximized biomass production and maintained stands, and more frequent harvests would result in reduced yields. In Nebraska and Iowa, optimum biomass yields of "Cave-in-Rock" switchgrass were attained with a single harvest during anthesis (R3-R5; [102]). Biomass yields ranged from 10.5 to $12.6 \mathrm{Mg} \mathrm{ha}^{-1}$ year $^{-1}$, and quality stands were maintained throughout the study. However, in South Dakota and Wisconsin, harvesting in mid-August resulted in reduced stands and biomass yield over time [11]. They suggested delaying harvest until late summer or early autumn may be beneficial for long-term stand maintenance. These studies indicate that a single harvest system will likely optimize biomass-harvesting efficiency, but stand maintenance will determine harvesting periods. Net energy and economic studies recently completed by coauthors Vogel and Mitchell and others indicate that the net energy for switchgrass grown for cellulosic ethanol in field scale trials is similar to that estimated by Farrell et al. [29] and the potential farmgate feedstock cost from the multilocation field trials averaged $\$ 0.17 \mathrm{~L}^{-1}$ ethanol. Based on this information, cellulosic ethanol from switchgrass is economically feasible and significantly net energy positive.

\section{Sorghum}

Sorghum (Sorghum bicolor (L.) Moench) is the second most important feed grain grown in the US in terms of acreage (Fig. 1). Like switchgrass, it is a warm-season $\mathrm{C}_{4}$-species, but is diploid and grown as an annual, making it much more amenable for basic genetic research. Three different components of the sorghum plant are used as bioenergy substrate: grain, fodder (leaves and stems), and the juice from sweet sorghums. Sorghum is extremely important to producers in marginal rainfall areas. Production is focused in the Southern portion of the Central Great Plains of the US (Fig. 1), and is expected to increase in importance to numerous producers as energy costs and water availability for irrigation become more and more limiting. Shifts in production and use are occurring currently due to rapid expansion of grain-based ethanol distilleries. This is already evidenced in a $19 \%$ increase in sorghum acreage in 2007 as compared to 2006 [65]. 
In addition to its obvious value as a major bioenergy feedstock, sorghum particularly useful as a bioenergy research model in that numerous genes affecting feedstock quality are known. Several compellations of sorghum genes and associated phenotypes are available, with the most recent being W.L. Rooney's [77]. Three groups of bioenergy related genes, the brown midrib genes (bmr), low amylose or waxy endosperm genes $(w x)$, and sweet genes, are the subject of current hybrid and market development. Although each has been researched in the past, primarily at the whole-plant level, considerable work remains to fully understand and utilize these genes in sorghum and other bioenergy crops.

Brown midrib mutants with reduced lignin content have been exploited in Sorghum breeding programs, and have great utility in developing Sorghum plants for bioenergy. Three mutant genes, $b m r-6, b m r-12$ and $b m r-18$, have been identified as most agronomically acceptable [31]. The $b m r$ 12 and $b m r-18$ genes are allelic [5], and the $b m r-6$, and the bmr-12 and -18 genes are located at two independent loci [37]. The $b m r-6$ gene has been associated with a decrease in cinnamyl alcohol dehydrogenase (CAD) activity [10], while the allelic $b m r-12$ and $b m r-18$ genes decrease caffeic acid $O$-methyl transferase (OMT) activity [8]. Both loci result in reduced lignin content.

Using two sets of sorghum near-isolines representing ten different genetic backgrounds [72-74], it was demonstrated that $b m r-12$ was generally superior to $b m r-6$ for decreasing lignin content and increasing fiber digestibility $[67,68]$. The yield reduction commonly associated with the brown midrib phenotype [74] could be overcome by heterosis in an isogenic hybrid, bmr-12 Awheatland $\times$ RT $\times 430$, when compared to its isogenic wild-type hybrid [68]. These near-isolines, plus an additional set of lines with stacked $b m r-6$ and $b m r-12$ genes developed near-isogenic to three of the previously released sets, serve as the basis for continuing work on cell walls. Using the lignin biosynthetic genes from Arabidopsis and other plants as a template, putative homologous genes from Sorghum have been identified and are under investigation in the various near isogenic lines described above (Sattler, Pedersen, Funnell, unpublished). Determining the effects of these key genes will have positive implications for improving sorghum and other $\mathrm{C}_{4}$-grasses as biofuel feedstocks.

Although reduction in lignification of plant tissues is widely held to reduce general fitness [75], perturbations of the lignin biosynthetic pathway may unexpectedly affect plant responses to pathogens in a positive fashion [32]. These results suggest that impaired lignin synthesis in sorghum may lead to an accumulation of other classes of compounds from phenylpropanoid metabolism, which directly inhibit the growth of sorghum pathogens. These findings could have future applications in developing sorghum as a potential chemical feedstock.

The waxy phenotype in sorghum is associated with endosperm starch lacking amylose (a glucose polymer with straight chains), and composed of nearly $100 \%$ amylopectin (a glucose polymer with branched chains). Pedersen et al. [70] discovered the existence of two waxy alleles, $w x^{a}$ and $w x^{b}$. Waxy lines with $w x^{a}$ produce no detectable granulebound starch synthase (GBSS). In waxy lines carrying $w x^{b}$, GBSS is produced, but is evidently non-functional. In a subsequent study surveying distribution of these alleles in the U.S. photoperiod insensitive sorghum collection, Pedersen et al. [71] found that 4 of 28 waxy lines contained the $w x^{b}$ alleles, which can be exploited in breeding programs to develop plants with modified starch. Presence or absence of amylose has significant impact on the physicochemical properties of starch. Amylose can form a firm gel, while amylopectin exhibits low syneresis and high resistance to retrogradation [94]. Recent work by $\mathrm{Wu}$ et al. [111] suggests that low amylose content in sorghum grain may be associated with increased ethanol conversion efficiency. Other recent research indicates that the waxy trait also is associated with reduced sorghum grain yields, but that this yield reduction can be overcome by intensive breeding [78].

In addition to simply inherited traits such as brown midrib, waxy endosperm, and sweetness, considerable research has been devoted to improving quantitative traits of importance to bioenergy production. Recently published results showed significant variation in the U.S. photoperiod insensitive sorghum collection for many chemical and nutritional traits including starch content of grain which varied from 64 to $73 \%$ [40]. Development of highly fermentable and highly digestible lines has already been accomplished in maize and hybrids purported to increase ethanol yields by $3-5 \%$ are currently available from major seed companies. Purposeful development of such lines has lagged in sorghum, but the potential may be even greater than in maize. Wu et al. [111] reported a $22 \%$ variation in sorghum ethanol yields and $9 \%$ variation in conversion efficiencies. They also noted significant differences in rates of fermentation and hypothesized that this would play an important role in ethanol distillery capacity.

Sweet sorghum is cultivated for its sugar, and can accumulate $15-23 \%$ fermentable sugars and the juice can be extracted by pressing the stems. Sweet sorghum can be cultivated in areas where grain sorghum is raised, and is currently grown mostly for forage. If methods can be optimized to rapidly ferment pressed juice, sweet sorghum could serve as an alternate bioenergy crop. The residue left over after pressing for juice could be used as a source of lignocellulose for fermentation, or alternatively burned as a direct source of energy. Incorporation of $b m r$ genes into 
sweet sorghum plants could provide high-quality lignocellulosic residues in addition to crushed juice. Development of appropriate harvest, storage and fermentation technologies could potentially make sweet sorghum an attractive bioenergy crop (Dr. I. Dweikat, University of NebraskaLincoln, personal communication).

\section{Wheat}

Common wheat (Triticum aestivum L.) is one of the world's most widely cultivated crops. World-wheat production for 2007 was forecast as 592 million tons, second in production only to maize, with a projected forecast of 694 million tons (FAO [28]). Wheat is grown on all continents except Antartica, and wheat breeders have developed types that are capable of being seeded from sub-tropical to far northern latitudes. The large number of seeded acres in so many diverse environments makes wheat an attractive source of biomass for biofuel production (Fig. 1). Three different products of the wheat plant have been investigated as sources of biofuel. These are wheat straw (primarily lignocellulose), grain (primarily starch) and millers by-products (mixed cellulose and starch).

Estimated ethanol yields from wheat straw vary with pre-treatments. Utilizing a hydrothermal pre-treatment which included acid hydrolysis, wet oxidation and steam, followed by simultaneous saccharification and yeast fermentation, Thomsen et al. [95] reported ethanol yields of $223 \mathrm{~kg}$ ethanol ton ${ }^{-1}$ straw. Using alkaline peroxide pretreatment, and fermentation via recombinant $E$. coli strain FBR 5, Saha and Cotta [80] achieved yields of $290 \mathrm{~kg}$ ethanol ton ${ }^{-1}$ straw. Ethanol yields also likely will vary with environment, and genotype of wheat used to generate straw.

Wheat straw represents an attractive source of biomass, as it would utilize agricultural residue, while still allowing the harvest of grain for feed. Removal of straw for biofuel production, however, must be balanced with the need to replenish soil organic matter and control erosion via sustainable reduced tillage production systems [45]. Many studies in maize systems [48, 51, 109] have demonstrated negative effects on soil composition and fertility as consequences of long-term removal of field stubble (residue). The "sustainable amount of crop residue" is environmentally dependent upon factors such as land slope and erodability, climate, precipitation, soil texture, organic matter, and wind conditions in production regions. In many regions where wheat is produced, wind erosion is the primary erosion problem and a minimum amount of stubble and crop residue must remain on the land to prevent soil loss due to wind. For example Shahbazi and $\mathrm{Li}$ [86] estimated a removal fraction of not more than $35 \%$ as being appropriate from North Carolina wheat fields. On a nationwide basis, however, Johnson et al. [45] estimated that there is not sufficient annual production of wheat non-grain biomass to replenish annual soil organic carbon loss. In other words, harvest of wheat stubble for biofuel, from current US wheat production zones, need to be monitored carefully to ensure sustainability of yield and return of soil organic carbon.

Economic factors also must be considered when contemplating the use of wheat stubble as a raw material in biofuel generation. Shahbazi and $\mathrm{Li}$ [86] noted that one-third of the cost of converting wheat straw to ethanol may be attributed to the cost of feedstock. These costs need to be evaluated in conjunction with production systems and sustainability as described above.

Wheat grain is a potential direct starch source for ethanol production but currently is not used for that purpose because starch from corn or sorghum is significantly cheaper. Because of its direct use for human consumption, a price differential will likely continue to exist for wheat grain in comparison to corn and sorghum. Wheat grain will probably be used for ethanol production only when crop surpluses depress the price of the crop.

Because of its use in food products, a significant amount of information exists on wheat starch composition. Until recently, little has been done to exploit genetic variation in wheat starch properties for energy. Such variation exists and information from wheats differing in starch properties could be used to develop grains that could be more efficiently converted to biofuels. Wild-type wheat starch is composed of approximately $75 \%$ amylopectin and $25 \%$ amylose. In the early 1990s Nakamura and colleagues [62, 63] devised strategies to separate GBSS proteins in wheat. Electrophoretic techniques demonstrated the existence of three distinct GBSS isoforms in wild-type wheat and the existence of non-functional (null) alleles in the waxy genotypes. Further, it was demonstrated [63] that null alleles at one or more waxy loci led to the production of wheat starch with reduced amylose content termed "partial waxy" wheats. Finally, by traditional intermatings of lines carrying the three null alleles, Nakamura et al. [64] were able to develop lines with no functional GBSS and no amylose. Amylose-free wheats, following the convention established in other cereal crops, are termed "waxy."

Limited research has demonstrated waxy wheats to be more efficient substrates for ethanol production. $\mathrm{Wu}$ et al. [112], observed higher efficiency of ethanol production from waxy wheat as compared to that of normal wheat, corn of various amylose contents, and waxy and non-waxy sorghum.

Lower temperatures are required to gelatinize waxy wheat [35], a necessary first step in the production of starch-derived ethanol. After cooking to $85^{\circ} \mathrm{C}$, waxy wheat starch essentially has lost all of its structure, making the 
chains readily accessible for digestion by enzymes employed in the ethanol production process. Thus, the lower energy input required for gelatinization of waxy starch represents another possible advantage in biofuels production. While the heat used for liquefaction in fuel ethanol production is a very small portion of the overall energy used, the combination of lower energy and the potential for faster fermentations or higher overall yields could be beneficial to fuel ethanol process economics.

An additional wheat resource for ethanol production is milling by-products. Das Neves et al. [23] studied ethanol generation from "low-grade wheat flour" which is essentially bran with some residual flour attached. It is generated as a milling by-product, and typically is used as an animal feed. Ethanol yield of $0.17 \mathrm{~g}$ ethanol $\mathrm{g}$ flour $^{-1}$ was observed for the low-grade wheat flour, as opposed to a value of $0.30 \mathrm{~g}$ ethanol $\mathrm{g}$ flour ${ }^{-1}$ for wheat flour per se. Vidmantiene et al. [99] hydrolyzed the polysaccharides from wheat and rye bran using a mixture of amylolytic and hemicellulolytic/cellulolytic enzymes. Ethanol yields of bran were compared to that of whole grain. Results demonstrated slightly higher ethanol yields from bran for both the species tested. The future use of milling by-products for biofuels will be dependent on their value as livestock feed in comparison to its value as a bioenergy feedstock.

Ethanol yields per unit of land area for wheat grain and biomass are largely a function of yield, which is affected by management, environmental conditions, and genetics. Rosenberger et al. [79] estimated ethanol yields from winter wheat grain at a maximum of $3,453 \mathrm{~L}$ ethanol hawhen wheat plantings followed pea in rotation. With continuous wheat cropping, lower yields were observed. Similar responses were noted for triticale (X Triticosecale) and for winter rye (Secale cereale), with triticale being observed as being the most efficient, in terms of cost per $\mathrm{L}$ of ethanol generated. Again, production costs and ethanol yields were dependent on previous crop, soil, and environmental factors.

\section{Conclusions}

Significant opportunities exist to grow forages and small grains for bioenergy. Advances in genetics and agronomics are likely to fuel the first phase in feedstock development. Developing sorghum (a diploid species) as a model for $\mathrm{C}_{4}$ grasses is likely to yield important insights into genetics and trait manipulation in polyploid species, such as switchgrass. For switchgrass and sorghum grown for biomass, the short-term realization (5-10 years) in improved yield and quality are likely to be significant. For wheat because of its higher value as a staple food, its use for starch-based biofuels will be more limited. However, significant research information may be obtained from the use of wheat differing in grain composition on biofuel production. Although the actual tonnage of available wheat stalk residue in the US, and the long-term impact of removing wheat stubble on yield and soil health are not fully known, wheat straw is currently serving a vital function as a model feedstock in cellulosic feedstock conversion research. There will be crop production regions where wheat and other small grain residues can be sustainably used as a biorefinery feedstock.

An absence of operational biorefineries in the continental US introduces a certain level of uncertainty into the breeding and optimization of feedstocks for specific conversion platforms that will be utilized to produce liquid fuels; however, assuming some degree of equivalency in the composition of herbaceous feedstock and biorefinery conversion platforms, production of adequate levels of biomass from dedicated crops such as switchgrass or forage sorghums on rain-fed marginal lands appears to be an achievable goal. Feedstock composition is a complex end product between the genetic make-up of the plant and environmental conditions during its growth and there is still much to learn about the genetic interactions of traits important for bioenergy in these plants.

To support future biorefineries and deliver the tonnage of biomass required, feedstock improvement will have to occur through utilization of appropriate analytical platforms within a complex breeding, management and conversion program in the confines of a holistic sustainable structure (Fig. 3). As shown in Fig. 3, the various sub-components for utilizing herbaceous feedstocks for biofuels are inter-related and improvements in any one sector is likely to have a synergistic, feed forward effect on the development of these feedstocks. However, continued utilization and production of biomass will be dependent on thoroughly

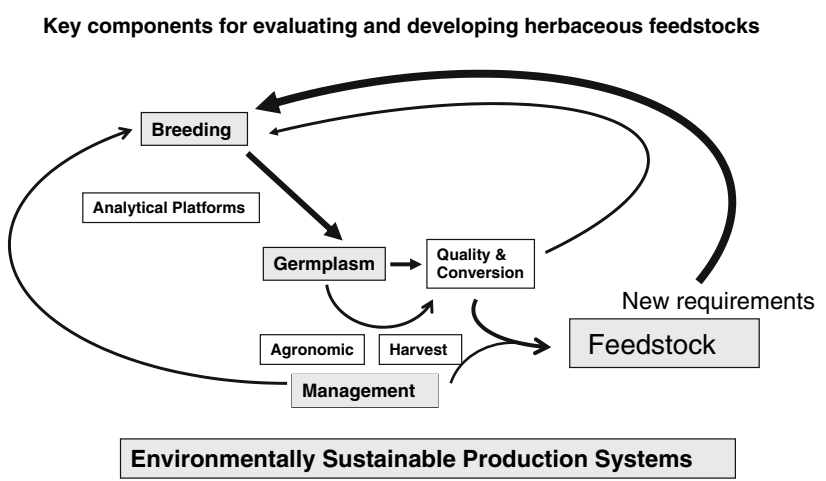

Fig. 3 Development of herbaceous feedstocks needs to occur in an environmentally sustainable manner. This figure highlights the different components needed for evaluating, developing and producing plants with superior bioenergy traits. These studies encompass basic and applied research, and all are interrelated and necessary for developing future bioenergy crops. It is expected that breakthroughs in any one area will positively impact other components in a feedstock development program 
documenting the positive and negative environmental and economic impacts of production systems.

Some significant challenges lie ahead. Major hurdles will be proving the economic effectiveness of lignocellulosic biorefineries and the ability to sustainably produce the tonnage of feedstock required within a given region (fuelshed) to supply biorefineries. Currently, our knowledge on the potential impact of existing or new biotic stress on dedicated bioenergy feedstocks grown over large geographical areas is limited. For example, will breeding for higher conversion make the plants more susceptible to pests, pathogens or environmental stress? These issues will need to be addressed along with the deployment of new varieties and cultivars.

Potential impact of biotechnology for improving composition and plant properties of herbaceous feedstocks is in its infancy [43, 53, 90, 92, 93, 110], but represents an exciting area of research. The development of genetically engineered plants with improved feedstock properties could fast-track bioenergy exploitation; although widespread acceptance of these engineered plants are likely to face public opposition, especially for native prairie species such as switchgrass. Results from current studies on gene flow in native populations and proposed studies between genetically-modified (GM) plants and wild relatives will need to be assessed to determine the feasibility of planting acreages to GM bioenergy crops.

Despite these and other challenges, the current socioeconomic and scientific climate favors the utilization of herbaceous plants, crop residues and small grains for bioenergy. The advent of flexible biorefineries should permit exploitation of these multiple feedstocks and extend the projected environmental and economic benefits of biofuels. Finally, biorefineries situated in appropriate fuelsheds are likely to significantly improve rural economies and strengthen a rediversification of agriculture to once again provide food, fuel and feedstocks in an environmentally sustainable manner.

Acknowledgments We thank Dr. Lisa M. Baird (University of San Diego) for the scanning electron micrographs of switchgrass internodes. Mention of trade names or commercial products in this publication is solely for the purpose of providing specific information and does not imply recommendation or endorsement by the US Department of Agriculture.

\section{References}

1. Akin DE, Hanna WW, Rigsby LL (1986a) Normal-12 and brown midrib-12 sorghum. I. Variations in tissue digestibility. Agron J 78:827-831

2. Akin DE, Hanna WW, Snook ME, Himmelsbach DS, Barton FEI, Windham WR (1986b) Normal-12 and brown midrib-12 sorghum. II. Chemical variations and digestibility. Agron J 78:832-837
3. Adler PR, Sanderson MA, Boateng AA, Weimer PJ, Jung H-JG (2006) Biomass yield and biofuel quality of switchgrass harvested in fall or spring. Agron J 98:1518-1525

4. Barton FE 2nd, Windham WR (1988) Determination of aciddetergent fiber and crude protein in forages by near-infrared reflectance spectroscopy: collaborative study. J Assoc Off Anal Chem 71:1162-1167

5. Bittinger TS, Cantrell RP, Axtell JD (1981) Allelism tests of the brown midrib mutants of Sorghum. J Hered 72:147-148

6. Barrière Y, Ralph J, Mechin V, Guillaumie S, Grabber JH, Argillier O, Chabbert B, Lapierre C (2004) Genetic and molecular basis of grass cell wall biosynthesis and degradability. II. Lessons from brown-midrib mutants. C R Biol 327:847-860

7. Boerjan W, Ralph J, Baucher M (2003) Lignin biosynthesis. Annu Rev Plant Biol 54:519-46

8. Bout S, Vermerris W (2003) A candidate-gene approach to clone the sorghum Brown midrib gene encoding caffeic acid $O$-methyltransferase. Mol Genet Genomics 269:205-14

9. Bouton JH (2004) Improving switchgrass as a bioenergy crop for the Southeastern USA. Proc Am Forage Grass Council 13:348-351

10. Bucholtz DL, Cantrell RP, Axtell JD, Lechtenberg VL (1980) Lignin biochemistry of normal and brown midrib mutant sorghum. J Agric Food Chem 28:1239-1245

11. Casler MD, Boe AR (2003) Cultivar $\times$ environment interactions in switchgrass. Crop Sci 43:2226-2233

12. Casler MD, Buxton DR, Vogel KP (2002) Genetic modification of lignin concentration affects fitness of perennial herbaceous plants. Theor Appl Genet 104:127-131

13. Casler MD, Jung HJG (2006) Relationships of fibre, lignin, and phenolics to in vitro fibre digestibility in three perennial grasses. Anim Feed Sci Technol 125:151-161

14. Casler MD, Vogel KP (1999) Accomplishments and impact from breeding for increased forage nutritional value. Crop Sci 39:12-20

15. Casler MD, Vogel KP, Taliaferro CM, Wynia RL (2004) Latitudinal adaptation of switchgrass populations. Crop Sci 44:293-303

16. Cassman KG, Liska AJ (2007) Food and fuel for all: realistic or foolish? Biofuel Bioprod Bioref 1:18-23

17. Chen F, Dixon RA (2007) Lignin modification improves fermentable sugar yields for biofuel production. Nat Biotechnol 25:759-761

18. Chen F, Srinivasa Reddy MS, Temple S, Jackson L, Shadle G, Dixon RA (2006) Multi-site genetic modulation of monolignol biosynthesis suggests new routes for formation of syringyl lignin and wall-bound ferulic acid in alfalfa (Medicago sativa L.). Plant J 48:113-124

19. Cherney JH, Axtell JD, Hassen MM, Anliker KS (1988) Forage quality characterization of a chemically induced brown-midrib mutant in pearl millet. Crop Sci 28:783-778

20. Cherney JH, Cherney DJR, Akin DE, Axtell JD (1991) Potential of brown-midrib, low-lignin mutants for improving forage quality. Adv Agron 46:157-198

21. Cosgrove DJ (2005) Growth of the plant cell wall. Nat Rev Mol Cell Biol 6:850-861

22. Das MK, Fuentes RG, Taliaferro CM (2004) Genetic variability and trait relationships in switchgrass. Crop Sci 44:443-448

23. Das Neves M, Shimizu AN, Kimura T, Shiiba K (2007) Kinetics of bioethanol production from wheat milling by-products. J Food Process Eng 30:338-356

24. Degenhart NR, Werner BK, Burton GW (1995) Forage yield and quality of a brown mid-rib mutant in pearl millet. Crop Sci 35:986-988

25. Dien BS, Iten LB, Skory CD (2005) Converting herbaceous energy crops to bioethanol: a review with emphasis on pretreatment 
processes, In: Hou CT (ed), Handbook of Industrial biocatalysis, Taylor and Francis, Boca Raton, Fl, Chapter 23

26. Dien BS, Jung HG, Vogel KP, Casler MD, Lamb JFS, Weimer PJ, Iten L, Mitchell RB, Sarath G (2006) Chemical composition and response to dilute-acid pretreatment and enzymatic saccharification of alfalfa, reed canarygrass, and switchgrass. Biomass Bioenergy 30:880-891

27. Dixon RA, Chen F, Guo D, Parvathi K (2001) The biosynthesis of monolignols: a "metabolic grid", or independent pathways to guaiacyl and syringyl units? Phytochemistry 57:1069-1084

28. FAO (2006) Food outlook: Global market analysis. (ftp:// ftp.fao.org/docrep/fao/009/j8126e/j8126e00.pdf)

29. Farrell AE, Plevin RJ, Turner BT, Jones AD, O'Hare M, Kammen DM (2006) Ethanol can contribute to energy and environmental goals. Science 311:506-508

30. Frank AB, Berdahl JD, Hanson JD, Liebig MA, Johnson HA (2004) Biomass and carbon partitioning in switchgrass. Crop Sci 44:1391-1396

31. Fritz JO, Moore KJ, Jaster EH (1990) Digestion kinetics and cell wall composition of brown midrib sorghum $\times$ sudangrass morphological components. Crop Sci 30:213-219

32. Funnell DL, Pedersen JF (2006) Reaction of sorghum lines genetically modified for reduced lignin content to infection by Fusarium and Alternaria spp. Plant Dis 90:331-388

33. Gerhardt RL, Fritz JO, Moore KJ, Jaster EH (1994) Digestion kinetics and composition of normal and brown midrib sorghum morphological components. Crop Sci 34:1353-1361

34. Grabber JH, Jung GA, Hill RRJr (1991) Chemical composition of parenchyma and sclerenchyma cell walls isolated from orchardgrass and switchgrass. Crop Sci 31:1058-1065

35. Graybosch RA, Guo G, SheltonDR (2000) Aberrant falling numbers of waxy wheats independent of alpha-amylase activity. Cereal Chem 77:1-3

36. Guillaumie S, Pichon M, Martinant JP, Bosio M, Goffner D, Barriere Y (2007) Differential expression of phenylpropanoid and related genes in brown-midrib bm1, bm2, bm3, and bm4 young near-isogenic maize plants. Planta 226:235-250

37. Gupta SC (1995) Allelic relationships and inheritance of brown midrib trait in sorghum. J Hered 86:72-74

38. Hanna WW, Monson WG, Gaines TP (1981) IVDMD, total sugars, and lignin measurements on normal and brown midrib (bmr) sorghums at various stages of development. Agron J 73:10501052

39. Hill J, Nelson E, Tilman D, Polasky S, Tiffany D (2006) From the Cover: Environmental, economic, and energetic costs and benefits of biodiesel and ethanol biofuels. Proc Natl Acad Sci USA 103:11206-11210

40. Hooks T, Pedersen JF, Marx DB, Vogel KP (2006) Variation in the US photoperiod insensitive sorghum collection for chemical and nutritional traits. Crop Sci 46:751-757

41. Hopkins AA, Vogel KP, Moore KJ (1993) Predicted and realized gains from selection for in vitro dry matter digestibility and forage yield in switchgrass. Crop Sci 33:253-258

42. Hoskinson RL, Karlen DL, Birrell SJ, Radtke CW, Wilhelm WW (2007) Engineering, nutrient removal, and feedstock conversion evaluations of four corn stover harvest scenarios. Biomass Bioenergy 31:126-136

43. Howe A, Sato S, Dweikat I, Fromm M, Clemente T (2006) Rapid and reproducible Agrobacterium-mediated transformation of sorghum. Plant Cell Rep 25:784-791

44. Johansen JN, Vernhettes S, Hofte H (2006) The ins and outs of plant cell walls. Curr Opin Plant Biol 9:616-620

45. Johnson JMF, Coleman MD, Gesch R, Jaradat A, Mitchell RB, Reicosky D, Wilhelm WW (2007) Biomass-bioenergy crops in the United States: a changing paradigm. Americas J Plant Sci Biotechnol 1:1-28
46. Jung HG, Mertens DR, Payne AJ (1997) Correlation of acid detergent lignin and Klason lignin with digestibility of forage dry matter and neutral detergent fiber. J Dairy Sci 80:1622-1628

47. Jung HG, Varel VH (1988) Influence of forage type on ruminal bacterial populations and subsequent in vitro fiber digestion. J Dairy Sci 71:1526-1535

48. Karlen DL, Wollenhaupt NC, Erbach DC, Berry EC, Swan JB, Each NS, Jordahl JL (1994) Crop residue effects on soil quality following 10-years of no-till corn. Soil Tillage Res 31:149-167

49. Lee DK, Boe A (2005) Biomass production of switchgrass in central South Dakota. Crop Sci Soc Am 45:2583-2590

50. Lerouxel O, Cavalier DM, Liepman AH, Keegstra K (2006) Biosynthesis of plant cell wall polysaccharides-a complex process. Curr Opin Plant Biol 9:621-630

51. Lindstrom MJ, Voorhees WB, Onstad CA (1984) Tillage systems and residue cover effects on infiltration in northwestern Corn Belt soils. J Soil Water Conserv 39:64-68

52. Liu ZL, Slininger PJ, Gorsich SW (2005) Enhanced biotransformation of furfural and hydroxymethylfurfural by newly developed ethanologenic yeast strains. Appl Biochem Biotechnol 121124:451-460

53. McLaren JS (2005) Crop biotechnology provides an opportunity to develop a sustainable future. Trends Biotechnol 23:339-342

54. McLaughlin SB, Kszos LA (2005) Development of switchgrass (Panicum virgatum) as a bioenergy feedstock in the United States. Biomass Bioenergy 28:515-535

55. Mielenz JR (2006) Bioenergy for ethanol and beyond. Curr Opin Biotechnol 17:303-4

56. Missaoui AM, Fasoula VA, Bouton JH (2005) The effect of low plant density on response to selection for biomass production in switchgrass. Euphytica 142:1-12

57. Missaoui AM, Paterson AH, Bouton JH (2005) Investigation of genomic organization in switchgrass (Panicum virgatum L.) using DNA markers. Theor Appl Genet 110:1372-1383

58. Mitchell RB, Anderson BE, Masters RA, Vogel KP, Klopfenstein TJ (2005a) Grazing evaluation of big bluestems bred for improved forage yield and digestibility. Crop Sci 45:22882292

59. Mitchell RB, Vogel KP, Varvel G, Klopfenstein T, Clark D, Anderson B (2005b) Big Bluestem pastures in the Great Plains: an alternative to dryland corn. Rangelands 27:31-35

60. Morris D (2006) The next economy: from dead carbon to living carbon. J Sci Food Agric 86:1743-1746

61. Mulkey VR, Lee DK, Owens VN (2006) Management of switchgrass-dominated Conservation Reserve Program lands for biomass production in South Dakota. Crop Sci 46:712-720

62. Nakamura T, Yamamori M, Hidaka S, Hoshino T (1992) Expression of HMW wx protein in Japanese common wheat (Triticum aestivum L.) cultivars. Jpn J Breed 42:681-685

63. Nakamura T, Yamamori M, Hirano H, Hidaka S (1993) Decrease of waxy $(\mathrm{Wx})$ protein in two common wheat cultivars with low amylose content. Plant Breed 111:99-105

64. Nakamura T, Yamamori M, Hirano H, Hidaka S, Nagamine T (1995) Production of waxy (amylose-free) wheats. Mol Gen Genet 248:253-259

65. NASS (2007) Acreage June 2007. Agricultural Statistics Board. USDA, NASS

66. Nelson RG, Ascough JC 2nd, Langemeier MR (2005) Environmental and economic analysis of switchgrass production for water quality improvement in northeast Kansas. J Environ Manage 79:336-347

67. Oliver AL, Pedersen JF, Grant RJ, KlopfensteinTJ (2005a) Comparative effects of the sorghum bmr-6 and bmr-12 genes I: forage sorghum yield and quality. Crop Sci 45:2234-2239

68. Oliver AL, Pedersen JF, Grant RJ, Klopfenstein TJ, Jose HD (2005b) Comparative effects of the sorghum bmr-6 and bmr-12 
genes II: grain sorghum grain yield, stover yield, and stover quality. Crop Sci 45:2240-2245

69. Parrish DJ, Fike JH (2005) The biology and agronomy of switchgrass for biofuels. Crit Rev Plant Sci 24:423-459

70. Pedersen JF, Bean SR, Graybosch RA, Park SH, Tilley M (2005a) Characterization of waxy grain sorghum lines in relation to granule-bound starch synthase. Euphytica 144:151-156

71. Pedersen JF, Graybosch RA, Funnell DL (2007) Occurrence of the waxy alleles wxa and wxb in waxy Sorghum Plant Introductions and their effect on starch thermal properties. Crop Sci 145:(in press)

72. Pedersen JF, Funnell DL, Toy JJ, Oliver AL, Grant RJ (2006a) Registration of 'Atlas bmr-12' forage sorghum. Crop Sci 46:478

73. Pedersen JF, Funnell DL, Toy JJ, Oliver AL, Grant RJ (2006b) Registration of seven forage sorghum genetic stocks near-isogenic for the brown midrib genes bmr-6 and bmr-12. Crop Sci 46:490-491

74. Pedersen JF, Funnell DL, Toy JJ, Oliver AL, Grant RJ (2006c) Registration of 12 grain sorghum genetic stocks near-isogenic for the brown midrib genes bmr-6 and bmr-12. Crop Sci 46:491-492

75. Pedersen JF, Funnell DL, Vogel KP (2005) Impact of reduced lignin on plant fitness. Crop Sci 45:812-819

76. Ragauskas AJ, Williams CK, Davison BH, Britovsek G, Cairney J, Eckert CA, Frederick WJ Jr, Hallett JP, Leak DJ, Liotta CL, Mielenz JR, Murphy R, Templer R, Tschaplinski T (2006) The path forward for biofuels and biomaterials. Science 311:484-489

77. Rooney WL (2000) Genetics and cytogenetics. In: Smith CW, Frederiksen RA (eds) Sorghum: origin, history, technology, and production. Wiley, NY, pp 261-307

78. Rooney WL, Aydin S, Kuhlman LC (2005) Assessing the relationship between endosperm type and grain yield potential in sorghum (Sorghum bicolor L. Moench). Field Crops Res 14:199-205

79. Rosenberger A, Kaul HP, Senn T, Aufhammer W (2002) Costs of bioethanol production from winter cereals: the effect of growing conditions and crop production intensity levels. Indust Crops Prod 15:91-102

80. Saha BC, Cotta MA (2006) Ethanol production from alkaline peroxide pretreated enzymatically saccharified wheat straw. Biotechnol Prog 22:449-453

81. Sanderson MA, Adler PR, Boateng A, Casler MD, Sarath G (2006) Switchgrass as a biofuels feedstock in the USA. Can J Plant Sci 86:1315-1325

82. Sanderson MA, Read JC, Reed RL (1999) Harvest management of switchgrass for biomass feedstock and forage production. Agron J 91:5-10

83. Sarath G, Baird LM, Vogel KP, Mitchell RB (2007) Internode structure and cell wall composition in maturing tillers of switchgrass (Panicum virgatum. L). Bioresour Technol 98:2985-2992

84. Sarath G, Vogel KP, Mitchell RB, Baird LM (2005) Stem anatomy of switchgrass plants developed by divergent breeding cycles for tiller digestibility. Intl Grasslands Cong Proc, pp: 115

85. Schmer MR, Vogel KP, Mitchell RB, Moser LE, Eskridge KM, Perrin RK (2006) Establishment stand thresholds for switchgrass grown as a bioenergy crop. Crop Sci 46:157-161

86. Shahbazi A, Li Y (2005) Availability of crop residues as sustainable feedstock for bioethanol production in North Carolina. Appl Biochem Biotechnol 129:41-54

87. Shadle G, Chen F, Srinivasa Reddy MS, Jackson L, Nakashima J, Dixon RA (2007) Down-regulation of hydroxycinnamoyl CoA: Shikimate hydroxycinnamoyl transferase in transgenic alfalfa affects lignification, development and forage quality. Phytochemistry 68:1521-1529

88. Shi C, Koch G, Ouzunova M, Wenzel G, Zein I, Lubberstedt T (2006) Comparison of maize brown-midrib isogenic lines by cellular UV-microspectrophotometry and comparative transcript profiling. Plant Mol Biol 62:697-714

89. Shi C, Uzarowska A, Ouzunova M, Landbeck M, Wenzel G, Lubberstedt $T$ (2007) Identification of candidate genes associated with cell wall digestibility and eQTL (expression quantitative trait loci) analysis in a Flint $\times$ Flint maize recombinant inbred line population. BMC Genomics 8:22

90. Shrawat AK, Lorz H (2006) Agrobacterium-mediated transformation of cereals: a promising approach crossing barriers. Plant Biotechnol J 4:575-603

91. Smart AJ, Schacht WH, Moser LE, Volesky JD (2004) Prediction of leaf/stem ratio using Near-Infrared Reflectance Spectroscopy (NIRS): A technical note. Agron J 96:316-318

92. Somleva MN (2006) Switchgrass (Panicum virgatum L.). Methods Mol Biol 344:65-73

93. Sticklen M (2006) Plant genetic engineering to improve biomass characteristics for biofuels. Curr Opin Biotechnol 17:315-319

94. Takahiro N, Nishiba Y, Sato T, Suda I (2003) Properties of starches from several low-amylose rice cultivars. Cereal Chem 80:193-197

95. Thomsen MH, Thygesen A, Jorgensen H, Larsen J, Christensen BH, Thomsen AB (2006) Preliminary results on optimization of pilot scale pretreatment of wheat straw used in coproduction of bioethanol and electricity. Appl Biochem Biotechnol 129$132: 448-460$

96. Tilman D, Hill J, Lehman C (2006) Carbon-negative biofuels from low-input high-diversity grassland biomass. Science 314:1598-1600

97. Tobias CM, Twigg P, Hayden DM, Vogel KP, Mitchell RM, Lazo GR, Chow EK, Sarath G (2005) Gene discovery and the identification of associated short tandem repeats in switchgrass: a C4 perennial grass. Theor Appl Genet 111:956-964

98. Tobias CM, Hayden DM, Twigg P, Sarath G (2006) Genic microsatellite markers derived from EST sequences of switchgrass (Panicum virgatum L.). Mol Ecol Notes 6:185-187

99. Vidmantiene D, Juodeikiene G, Basinskiene L (2006) Technical ethanol production from waste of cereals and its products using a complex enzyme preparation. J Sci Food Agric 86:1732-1736

100. Vogel KP (1996) Energy Production from Forages (or American Agriculture - Back to the Future). J Soil Water Conserv 51:137139

101. Vogel KP (2004) Switchgrass. In: Moser LE, Sollenberger L, Burson B (eds) Warm-season (C4) grasses. ASA-CSSA-SSSA Monograph,. Madison. pp 561-588

102. Vogel KP, Brejda JJ, Walters DT, Buxton DR (2002) Switchgrass biomass production in the Midwest USA: harvest and nitrogen management. Agron J 94:413-420

103. Vogel KP, Hopkins AA, Moore KJ, Johnson KD, Carlson IT (2002) Winter survival in switchgrass populations bred for high IVDMD. Crop Sci 42:1857-1862

104. Vogel KP, Jung HJG (2001) Genetic modification of herbaceous plants for feed and fuel. Crit Rev Plant Sci 20:15-49

105. Vogel KP, Pedersen JF, Masterson SD, Toy JJ (1999) Evaluation of a filter bag system for NDF, ADF, and IVDMD forage analysis. Crop Sci 39:276-279

106. Vogel KP, Sarath G, Mitchell RB (2005) Divergent breeding for tiller digestibility modified leaf, sheath, and stem composition of switchgrass (Panicum virgatum L.). Intl Grasslands Cong Proc, pp 116

107. Weimer PJ, Dien BS, Springer TL, Vogel KP (2005) In vitro gas production as a surrogate measure of the fermentability of cellulosic biomass to ethanol. Appl Microbiol Biotechnol 67:52-58

108. Weimer PJ, Springer TL (2007) Fermentability of eastern gamagrass, big bluestem and sand bluestem grown across a wide variety of environments. Bioresour Technol 98:1615-1621 
109. WilhelmWW, Johnson JMF, Hatfield JL, Voorhees WB, Linden DR (2004) Crop and soil productivity response to corn residue removal: a review of the literature. Agron J 96:1-17

110. Wollenweber B, Porter JR, Lubberstedt T (2005) Need for multidisciplinary research towards a second green revolution. Curr Opin Plant Biol 8:337-341

111. Wu X, Zhao R, Bean SR, Seib PA, McLaren JS, Madl RL, Tuinstra M, Lenz MC, Wang D (2007) Factors impacting ethanol production from grain sorghum in the dry-grind process. Cereal Chem 84:130-136

112. Wu X, Zhao R, Wang D, Bean SR, Seib PA, Tuinstra MR, Campbell M, O'Brien A (2006) Effects of amylase, corn protein, and corn fiber contents on production of ethanol from starch-rich media. Cereal Chem 83:569-575 